\title{
Civilisations
}

Revue internationale d'anthropologie et de sciences

humaines

49 | 2002

Pain, fours et foyers des temps passés

\section{The stone and Middle Age ovens in Loess sites of Slovakia. Influences on their quality for food preparation}

Danica Staššíková-štukovská

\section{OpenEdition}

Journals

Édition électronique

URL : http://journals.openedition.org/civilisations/1799

DOI : 10.4000/civilisations. 1799

ISSN : 2032-0442

\section{Éditeur}

Institut de sociologie de l'Université Libre de Bruxelles

\section{Édition imprimée}

Date de publication : 3 juin 2002

Pagination : 259-269

ISBN : 0009-8140

ISSN : 0009-8140

\section{Référence électronique}

Danica Staššíková-štukovská, "The stone and Middle Age ovens in Loess sites of Slovakia. Influences on their quality for food preparation », Civilisations [En ligne], 49 | 2002, mis en ligne le 01 juin 2005, consulté le 20 avril 2019. URL : http://journals.openedition.org/civilisations/1799 ; DOI : 10.4000/ civilisations. 1799

Ce document a été généré automatiquement le 20 avril 2019.

(c) Tous droits réservés 


\title{
The stone and Middle Age ovens in Loess sites of Slovakia. Influences on their quality for food preparation
}

\author{
Danica Staššíková-štukovská
}

\section{Introduction}

In the past, many ovens and various types of hearths of the early and top Middle Ages were analysed in the Slovak and Czech professional literature. Maybe this has been caused also by the fact that this theme made it possible to confront results of archaeological excavations with those of ethnographic research and to seek for mutual and in many cases successful parallels (e.g. Mácala-Podoba 1998). The truth is that ovens for food preparation have only been analysed together with other ovens for special activities (pottery production, metallurgy, etc. - Hruby 1961, Skružny 1963). Some theories argue that open hearths are more suitable for food preparation whereas more complex oven construction used to be connected with a special activity. Bread-baking is one of them and among the oven types created by various authors clay ovens sunk into a loess soil have been most often considered to be used for this activity (Skružny 1963, 1980 ; Mácala-Podoba 1998, Ruttkay 1990). 
Fig. 1 : Bajc- Reconstruction of a clay oven sunk into a loess soil, 10 th century. (After M. Ruttkay, 1990, fig.7)

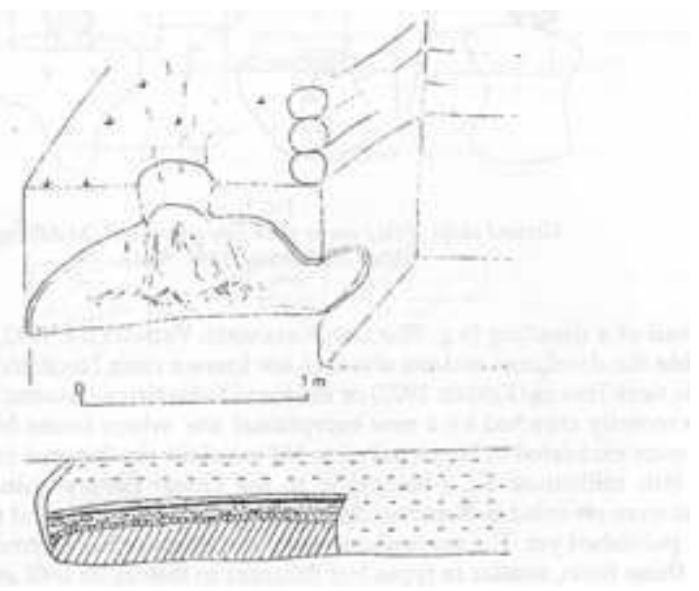

These so called bread ovens are known from a number of sites in central Europe that are dated from the 7th-12th centuries (Skružny 1963, 1980 ; Vignatiová 1992). A find of this type is usually represented by a hole sunk into a loess soil with the highest vaulting of 40-60 cm, red-burnt walls of 5-10 cm and a grey-burnt bottom, sometimes stone-lined.

The bottom ground plan is usually of renal, semi-circular up to round shape, east-west oriented.

4 From later periods (13 th century) it is documented that slightly modified ovens with an underground heating duct can serve for food-smoking (Skružny 1980). Archaeological finds of bread ovens are usually excavated on the margin of a settled area outside of the houses (Skružny, Vignatiová 1992, p. 90) or they are sunk into the wall of a dwelling (e.g. Breclav-Pohansko : Vignatiová 1992, fig. 3). The ovens outside the dwellings and the site area are known from Neolithic sites in Slovakia : in Pác near Trnava (Kolník 1977) or in Horné Lefantovce (Bánesz 1962). These finds were recently enriched by a new exceptional site where ovens from 11 th- 12 th century were excavated in the vicinity (ca. $150 \mathrm{~m}$ ) of the similar ones from the Late Stone Age (6 th millenium B.C.) belonging to the Linear-Pottery culture people. These ovens were revealed in Borovce, distr. of Piest'any, Slovakia, and the finds have not been published yet. The particular situation of Borovce has offered a chance to compare these finds, similar in types but different in history as well as in culture. 
Fig. 2 : Ground plans of clay ovens sunk into a Loess soil (Middle age). (After M. Ruttkay, 1990, fig.6)

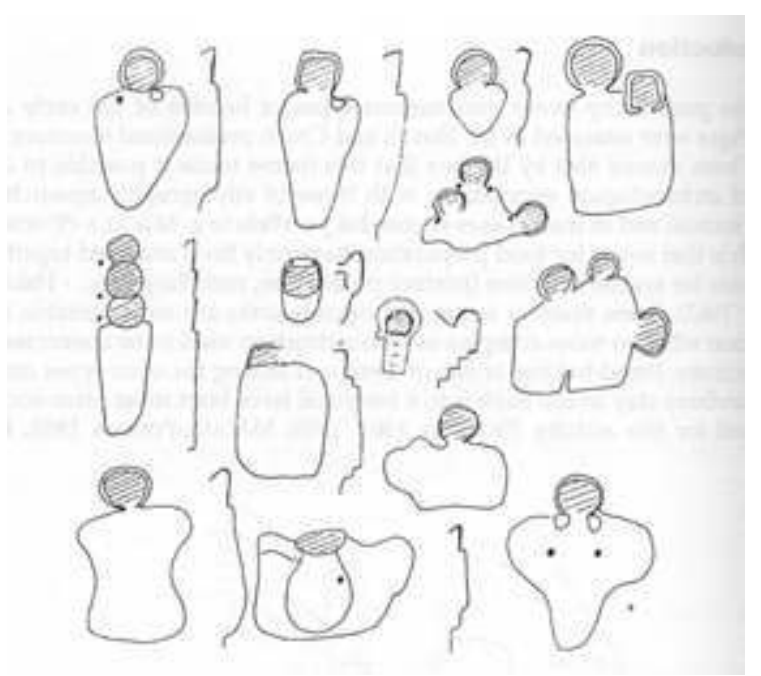

\section{The characterization of the site of Borovce}

Borovce is situated on the terrace of «Trnavská sprašová pahorkatina » (Trnava loess heights), $8 \mathrm{~km}$ south-west of a Piešt'any. The site, situated on the southern border of the town, is of polycultural character with remarkable finds mainly from the Late Stone Age (the Linear Pottery culture) and the Early up to Top Middle Ages (8th-13th century). Further less important finds are represented by settlement objects of the Aeneolithic, the Late Bronze Age and the Migration period. The soil of the site consists of a 15-25 m thick loess layer, covered by a 40-120 cm thick « chernozem » soil. The archaeological interest of the rescue excavations was centred on a remarkable cemetery of the 8 th- 11 th century. As the site is situated within the town borders, numerous objects have been damaged by recent building activities, including both medieval ovens. The ovens of different periods were excavated at three different places of the site. They were situated in such a way that imaginal connecting lines between them would create an approximative isosceles triangle with a group of three ovens from the Stone Age in its top and medieval ones on the opposite sides.

\section{The characterization of the Late Stone Age ovens ${ }^{1}$}

\subsection{Oven 1}

Oven 1 was the best preserved one and represented at $140 \mathrm{~cm}$ depth by a grey-burnt bottom with dimensions of $120 \times 135 \mathrm{~cm}$. It had $10 \mathrm{~cm}$ thick walls of burnt clay of a high of $60 \mathrm{~cm}$, and a partially preserved vault. Inside the oven fragments of globular vessels of the Late Linear Pottery culture were revealed (see J. Pavuk 1994. S. Šiška 1995. IllašováHovorka 1995 for recent informations on the Linear Pottery culture in Slovakia).

7 The oven was sunk into a $240 \mathrm{~cm}$ deep oval clay pit with a diameter of $8 \mathrm{~m}$ whose southern margin continuously passed into a later ditch of the Želiezovce culture. 
Fig. 3 : Borovce, distr. Piestany : 1-3 Ovens N.1,2,3, of the Late Stone Age, the (Linear Pottery culture), ground plans and profiles ; 4 - Oven N.4 (11th-12th century), ground plans and profiles ; 5 - Oven N.5 (11 th-12th century), ground plans and profiles : a- grey-burnt bottom, b- red-burnt walls, c- river pebbles, $d$ - destructed part.

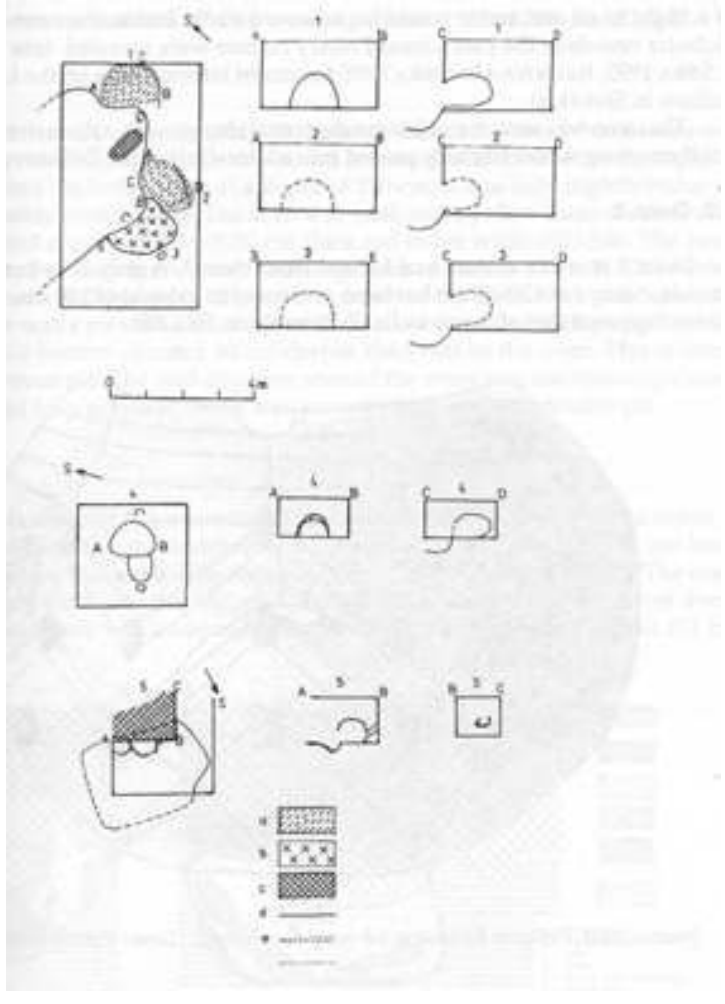

\subsection{Oven 2}

Oven 2 was at a distance of $130 \mathrm{~cm}$ from oven 1 . A grey-blue-burnt bottom of shoe-last shape of $120 \times 85 \mathrm{~cm}$ has been preserved in a depht of $120 \mathrm{~cm}$, together with $10 \mathrm{~cm}$ high remains of burnt walls $(7-10 \mathrm{~cm}$ thick, Fig.3 : 2)

Fig. 4 : Borovce, distr. Piestany : Reconstructed vessel from oven 1, Linear Pottery culture (ca.1/3).

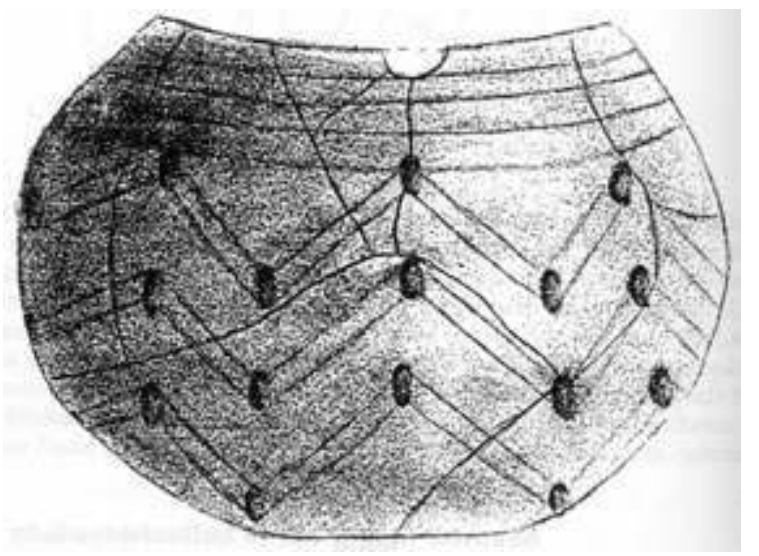




\subsection{Oven 3}

9 The bottom of oven 3, in a depth of $115 \mathrm{~cm}$, had a shoe-last shape with dimensions of $110 \times 180 \mathrm{~cm}$. It was made of sparse river pebbles and remains of a grey-blue-burnt bottom passing into the bottom of oven 2 . The walls of this oven have not been preserved (Fig.3: 3). The orientation of all ovens according to their longer axis was approximately north-south. The field situation allow us to presuppose that all ovens were originally sunk into the eastern wall of a clay pit and that differences in their preservation could be connected with damages from later periods.

\section{The characterization of the ovens of the 11 th-12th cent. A.D.}

\subsection{Oven 4}

Oven 4 was situated approximately $150 \mathrm{~m}$ south-east of the ovens 1-3. It was excavated during the building of a family-house basement and so time for its exploration was limited. Its bottom was at a depth of $120 \mathrm{~cm}$, it was only slightly burnt, of an approximately round shape. The oven was sunk into a yellow loess, its vault was $50 \mathrm{~cm}$ high and surrounded by $5-10 \mathrm{~cm}$ thick red-burnt walls (Fig.3: 4). The oven filling consisted of dark humus soil with fragmens of vessels of the 11-12th century, animal bones and pieces of charcoal. In front of the oven with west-oriented opening there was a pit with a diameter of $60 \mathrm{~cm}$, that was filled with pieces of charcoal and had a bottom situated $30 \mathrm{~cm}$ deeper than that of the oven. This is interpreted as an oven pit. The find situation around the oven was considerably damaged, so we can only presume that it was part of a bigger unidentifiable pit.

\subsection{Oven 5}

Oven 5 was situated $300 \mathrm{~m}$ north of oven 4 and $150 \mathrm{~m}$ north-east of the ovens 1-3. It was found during the building of a family-house basement too. It has been damaged in a way that gave us an unusual section of this find (Fig.3:5). The oven 5 was probably sunk into the wall of a "house pit", the bottom was $220 \mathrm{~cm}$ deep. The functional space was surrounded by the burnt walls of a loess vault $(10 \mathrm{~cm}$ thick red-burning) and its slightly burnt bottom of circular shape had dimensions of $100 \times 70 \mathrm{~cm}$. On the eastern side of the oven a thick layer of pieces of charcoal was found. At the western bottom rim a $20 \mathrm{~cm}$ wide strip of charcoal had a lengh of $80 \mathrm{~cm}$ and ended in a small vault (diameter $30 \mathrm{~cm}$ ) with remarkably burnt walls. The shape of the burning, together with that of a probable smoke outlet, was well observable on the section that had been formed by a corner of the house basement (Fig. $3: 5$ ). On this profile we could see the $5-7 \mathrm{~cm}$ red-burnt walls of the vault filled with charcoal and ash deposited aslantly. 
Fig. 5 : Borovce, distr. Piestany : Profiles A-B and B-C of the oven 5, Middle age. (ca.1/30).

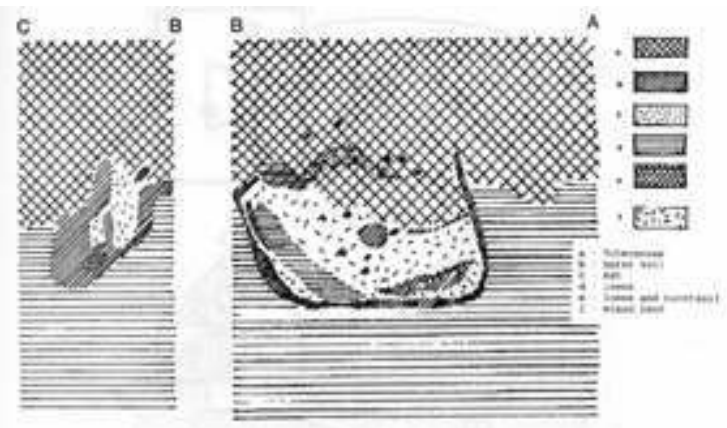

The oven fill consisted of vessel fragments of the 11-12 th century, charcoal and animal bones. An analogy to this find situation is known from Kudlovice (Czech Republik) where a similar oven sunk into a loessic parent material was excavated. It had a semi-circular ground plan (axis east-west), a width of $120 \mathrm{~cm}$, a depth $40 \mathrm{~cm}$ and a height of $30 \mathrm{~cm}$; the walls of the vault were red-burnt on $5-10 \mathrm{~cm}$. The smoke outlet had a diameter of $28-30 \mathrm{~cm}$ and it was broken aslantly into the surface of the oven (Skružny 1963, p.240, fig.10). We would like to underline that these smoke outlets of ovens, sunk into a loess soil, could be omitted á easily because of their small dimensions and greater distance from the oven. Considering their position closer to the earth surface, they are probably often damaged and only preserved in the form of unidentifiable daubt. But the construction of this opening can serve as an evidence for a good knowledge of warm-and cold-air flow. This indicates a certain skill in constructing ovens with the desired heating qualities. Warmth-conducting channels coming from underground ovens are known from finds of ovens of the 15th century, which used to be interpreted as corn of flax drying rooms, or smoking chambers (Skružny 1980, pp.230-231, fig. 8).

Fig. 6 : Kudlovice «Zamesa » (Uhersy Brod). Ground plan and profile of the oven sunk into loess layers. (After Skružny 1980)

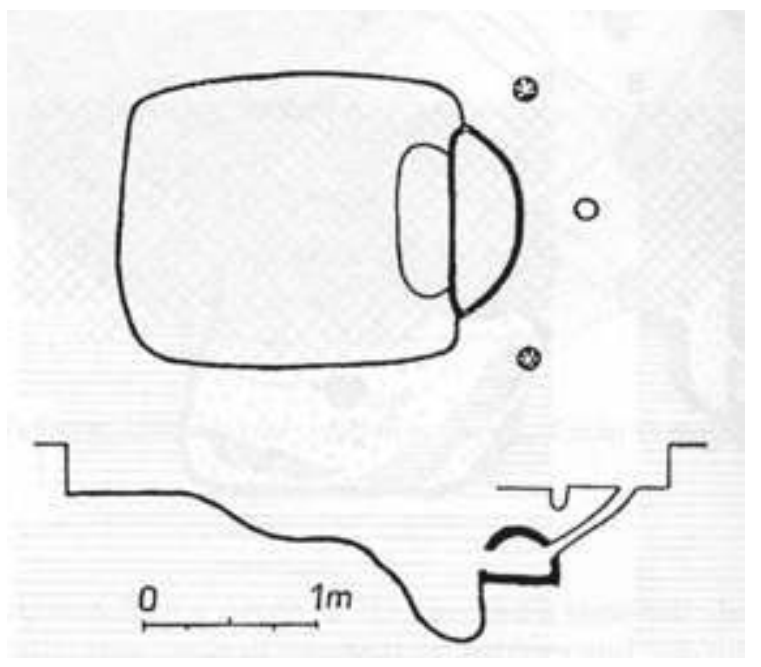




\section{Conclusions} there is very little or no difference between the Stone-Age ovens and those made in the Middle Ages. Dimensions of burnt bottoms and walls are conspicuously similar: the diameter of the Neolithic ovens was $80-110 \mathrm{~cm}$, the diameter of the medieval ones was $78-110 \mathrm{~cm}$. This observation could support the already stated opinion that these constructions reflect a technical advancement or special needs of a certain community, regardless of its ethnicity (review in Vignatoivá 1992, p.89; Skružny 1980, p.221). Some differences among the ovens of Borovce could be seen in the stages of burning of the bottoms. Two of the Neolithic ovens have grey-burnt bottoms, which means that their temperature had to be higher than $2000 \mathrm{C}$. These changes in a loess colour in relation to firing temperatures were experimentally tested in Borovce (Stašš́́ková-Štukovská 1989). The bottoms of the medieval ovens are not burnt, which means that the temperature was lower there. High temperatures are not necessary for bread-baking or food-smoking and this would correspond with the stage of burning of the medieval ovens. The temperature of the Neolithic ovens had to be higher for some time than that needed for bread-baking. This fact, of course, does not exclude this activity, as it is suggested also by other authors, e.g. in connection with pottery ovens in the Middle Ages (Skružny 1980). But the same time the find situation in Borovce supports the hypothesis of T. Kolnik articulated in connection with the find of a battery of 15 ovens of the éeliezovce culture (Neolithic) in Pac near Trnava (Slovakia). He suggested that ovens used to serve also for pottery-drying and he issued from findings of O. Sujanova that the Neolithic pottery was not burnt, but only dried in temperatures up to $200^{\circ} \mathrm{C}$ (Kolník 1978, p.134). He has applied this hypothesis also to the find of a battery consisting of 13 ovens in Lefantovce (Bánesz 1959, 1962).

Fig. 7 : Ground plan and profiles of a flax drying room. (After Skružny 1980, fig.8)

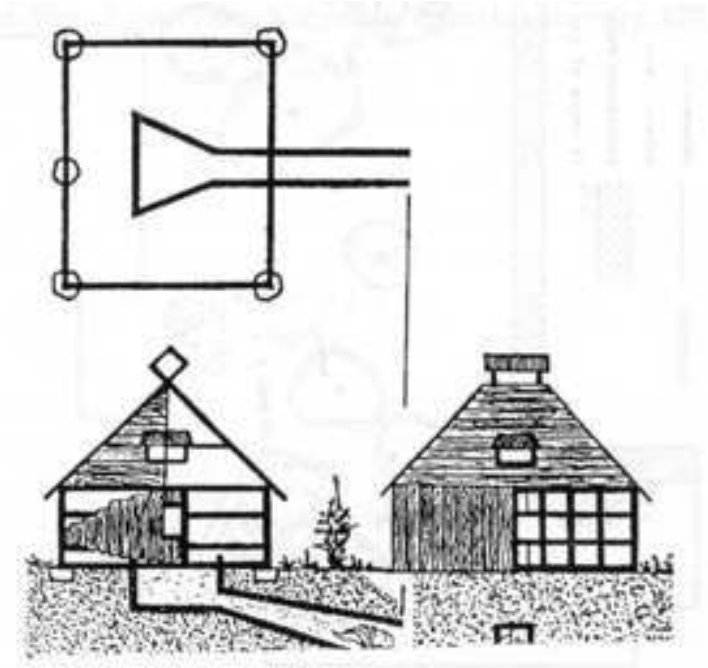
the walls and the bottoms bear basic information about an oven's function. In the case of Borovce, the stage of burning differed not only between the neolithic and the medieval ovens but also between one another. While the medieval ovens were similar 
according to their stage of burning, oven 5 presented an oblique smoke outlet, where as in oven 4 such an opening has not been found. Among the neolithic ovens there was a difference in the burning of the bottoms : the ovens 1 and 5 had a strongly burned bottom and oven 3 had a very slightly burnt bottom with pebbles. Maybe future studies of these characteristics could result in more precise interpretation of these « bread ovens".

As a conclusion we can state that the idea of concentrating heat in an underground vault - which is a good isolator and prevents from heat-loss - , was invented and utilized already in the Neolithic in central Europe. As far as their utility is concerned, these ovens were so effective that there was no need to improve them in later periods.

Fig. 8 : Horné Lefantovce - Plan of Neolithic objects with ovens. (After Bánesz 1962, fig.1)

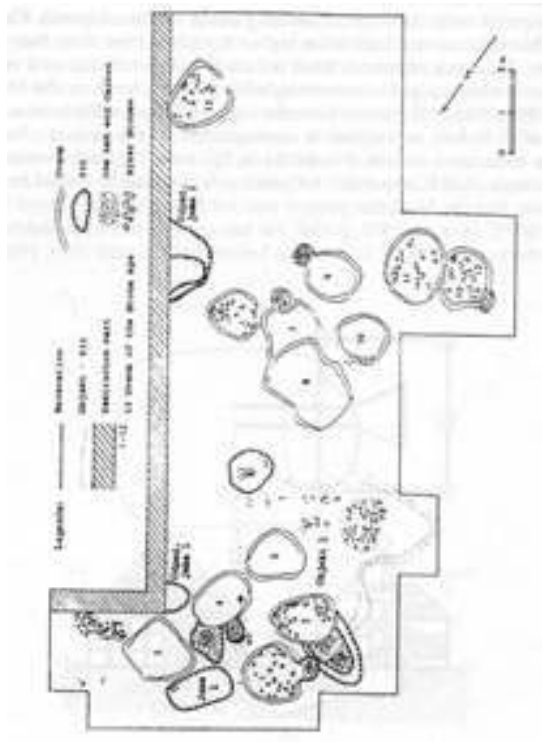

\section{BIBLIOGRAPHIE}

BÁNESZ, L., 1962. Neolitické nálezy z Hornych Lefantoviec, Študijné zvesti AU SAV, p. 21-46.

BÁNESZ, L., 1959. Neolitické nálezy z Hornych Lefantoviec, Archeologické Rozhledy 11, p. 470-482.

HRUBY, V. 1963. Príspevek k poznání velkomoravského obydlí, Památky Archeologické 52, p. $488-495$.

ILLAŠOVÁ, L., HOVORKA, D. 1995. Nephrite und Amphibolschiefer, Veröffentlichungen des Brandenburgischen Landesmuseums für Ur- und Frühgeschichte, Bd.29, p. 229-236.

KOLNík, T. 1978. Dalšia etapa vyskumu v Cíferi-Páci, AVANS 1977, Nitra, p. 128-137.

MAËALA, P.- PODOBA J. 1988. Vykurovacie zariadenia v dedinskom prostredí na Slovensku v 6. aû 20. Storocí, Historica Carpatica 1988, p. 143-160. 
PAVUK, J. 1994. Šturovo. Ein Siedlungsplatz der Kultur mit Linearkeramik und der Želiezoovce-Gruppe, Nitra.

RUTTKAY, M., 1990. Pece na rannostredovekych sidliskach juhozapadného Slovenska, Archaeologia Historica 15/90, p. 337-348.

SKRUŽNY, L. 1963. Príspeve k trideni a chronologii slovanskych otopnych zarizeni na uzemi CSSR, PA LIV-2, p. 234-265.

SKRUŽNY, L. 1980. Nekolik poznamek k otazce vyvoje a funkce pece ve slovanskych, stedovïkych a novovïkych objektech i mimo ne. Archaeologia Historica 5, p. 221-242.

STAŠŠíKoVÁ-šTUKovSKÁ, D. 1989. Pôsobenie tepla na spras. Archeologické Rozhledy XLI, p. 650-653.

ŠIšKA, S. 1995. Dokument o spolocnosti mladsej doby kamennej (Šarišské Michal'any), Bratislava.

VIGNATOIVÁ, J. 1992. K otazce puvodu a funkce hlinenych peci v zemnicich 9. stol. na Morave a na Slovensku, Sbornik praci Filozofické fakulty brnenské univerzity, E37, p .89-102.

\section{NOTES}

1. Marked from 1 for simplification

\section{RÉSUMÉS}

Dans cet article les fours du Néolithique ancien et du Haut au Bas Moyen-Age de Borovce en Slovaquie sont décrits avec précision et comparés. Ils sont situés sur des sols loessiques. Sur base des détails structurels, du type de rubéfaction, d'expérimentations et de la littérature, différentes interprétations sont proposées. Celles-ci comprennent la cuisson du pain et le séchage des poteries. En comparant les fours des différentes époques, nous pouvons affirmer qu'il n'y a pas ou peu de différences entre les fours du Néolithique et ceux construits au Moyen-Age. Ces fours étaient si efficaces qu'aucune amélioration ne semble avoir été nécessaire.

In this paper, the ovens of Borovce in Slovakia are described precisely and compared. They date from the Early Neolithic and from Early to Top Middle Ages and are situated on loess. On the basis of details of the construction, type of rubefaction, archaeological experiments and litterature, different interpretations are proposed. These involve breadmaking and the drying of pottery. Comparing the find circumstances of the ovens and those made in the Middle Ages. As far as their use is concerned, these ovens were so effective that there was no need to improve them in later periods.

\section{INDEX}

Mots-clés : Fours, néolithique, Moyen âge, Slovaquie

Keywords : Ovens, neolithic, Middle Age, Slovakia 
AUTEUR

DANICA STAŠŠÍKOVÁ-ŠTUKOVSKÁ

Archeologicky Ustav SAV, Nitra, Slovakia 